\title{
MAKING MANGOES Move
}

\section{Transforming Cultures eJ ournal, \\ Vol. 3 No 1, February 2008 http:// epress.lib.uts.edu.au/journals/TfC}

\section{Jodi Frawley ${ }^{1}$}

A landscape of mangoes most likely brings to mind $a$ place in a tropical location. By the end of the nineteenth century that place could have been located on any continent in the world. Mangoes were found in geographic locations; in scientific institutions; as crop plants; and as a backyard trees. Here I trace the movement of mangoes Mangifera indica Linn., focusing on the transnational links formed through colonial botanic gardens in Australia. Botanic gardens were largely understood through their work in establishing economically successful plantation crops, such as sugar and tea. Mangoes were not a success crop of the age of botanic imperialism. Instead, mangoes were simply one species among the millions of plants that botanic gardens moved in addition to these well known commercial crops. Colonial science moved plants for a myriad of other types of reasons, for ornament, for curiosity, for lesser commercial purposes and for pure science. In each site the mango emerged, the discourses and technologies that traveled with it changed according to local needs. Indeed, rather than finding mangoes located in one place, tracing their movement demonstrates that this was an extended landscape connecting these things across time and space.

In India the mango was a grove plant, with multiple uses across a spectrum of medicinal and culinary sites. Once captured by transnational science it became an artifact which was displaced and rendered into many representations. Repatriated into the Royal Botanic Gardens Kew and repeated into botanic gardens across the world, mangoes were articulated as a feature of science. Such thinking shifted to a mode of understanding mangoes as commercial economic botany. As commercial economic botany it was imbued with a sense of hope; a plant of potential that could accompany settlement in the remote part of the world that was Australia. When this venture failed,

\footnotetext{
${ }^{1}$ Jodi Frawley is a PhD student in Gender and Cultural Studies at the University of Sydney.
} 
the plant became something else in tropical Queensland, a backyard addition to domestic gardening. So one must ask, how might we understand $a$ landscape of meaning from this process? This was not a simple movement of an oriental plant into a European system of science, but required a series of moves, each accompanied by a rearticulation of the mango in each new setting. Is it possible to acknowledge that when mangoes moved, they did so as a series of representations and material realities?

Histories of plant exchange often concentrate on 'big' economic products like tea, cinchona and sugar stemming from the work of 'big' and 'important' botanic gardens, particularly the Royal Botanic Gardens at Kew. Since Lucile Brockway's groundbreaking work in the late 1970s, ${ }^{2}$ a number of authors have tackled the imperial role of botanic gardens. Central to the argument of these studies: the Royal Botanic Gardens, Kew developed a system of botanic gardens within the hierarchies of the British Empire. Donal McCraken, ${ }^{3}$ Richard Drayton ${ }^{4}$ and Ray Desmond ${ }^{5}$ each work within the archives generated by the botanic gardens of the nineteenth century. Each in their own way chronicles the development of botanic gardens within the British Empire and the common functions of series of botanic gardens in colonial locations. Desmond called Kew 'the botanical metropolis of the world" ${ }^{6}$ indicating a qualified importance of Kew in relation to other botanic gardens. Even as they argue for the impact of the colonial knowledges in environmental thought, as Richard Grove ${ }^{7}$ does, they articulate the sense that Kew was the overwhelming centre of botany and empire.

The prevailing idea here was that science was an aspect of the political hegemony of imperialism and that science was deliberately 'spread' through the empire. In each case science and its relation to economics dominates the relations between metropolitan

\footnotetext{
${ }^{2}$ Lucile Brockway, Science and Colonial Expansion: The Role of British Royal Botanic Gardens (New York: Academic Press, 1979).

${ }^{3}$ Donal McCracken, Gardens of Empire: Botanical Institutions of the Victorian British Empire (London: Leicester University Press, 1997).

${ }^{4}$ Richard Drayton, Nature's Government: Science, Imperial Britain and the 'Improvement' of the World (New Haven: Yale University Press, 2003).

${ }^{5}$ Ray Desmond, Kew:The History of the Royal Botanic Gardens (London: Harvill in association with the Royal Botanic Gardens Kew, 1998).

${ }^{6}$ Ibid., p.302.

${ }^{7}$ Richard Grove, Green Imperialism: Colonial Expansion, Tropical Island Edens, and the Origins of Environmentalism, 1600 -1860, Studies in Environment and History. (Cambridge; New York: Cambridge University Press, 1995).
} 
elites and colonial gardens discussed in this body of work. One of the features that emerged from this selection of works about botanic gardens was that they belonged to the process of domination of colonial environments primarily through the spread of science. While the part that they played in grand narratives of Empire were well considered and extremely important, there was a gap in the historical knowledge about these places in what may be tentatively considered the pervasive everyday functions of the movement of plants, plant material and plant information.

Close attention to the way that mangoes moved through colonial botanic gardens provides a way to account for these other histories. It was the way the mango circulated as a reference of colonial botany that became the constituting infrastructure of its movement. ${ }^{8}$ Bruno Latour argues that 'yes, scientists master the world, but only if the world comes to them in the form of two-dimensional, superposable, combinable inscriptions'. ${ }^{9}$ Scientists moved the environment through extracting singular specimens, here the mango, and translating them into the production of papers, specimens - both living and dead - letters, illustrations and photographs. These inscriptions were, for botanic gardens, the markers that help them to confidently negotiate the mango as part of a bigger world. This didn't just happen in Europe, but all over the world simultaneously. Scientific representation, regardless of which form it takes always links back to the living and to local ecosystems. Representations overcome distance, but they also transform or translate objects into something other than what they were in 'nature'.

It is not enough, however, to consider representation in isolation from other features of local environments. As an object moved as a textual representation, it was displaced and open to translation into knowledge, information and narratives creating new meaning in each local place. In Australia, botany and botanic gardens emerged as support mechanisms for settlement as environments underwent substantial change. In a local place, other things were inscribed to support the movement of mangoes: technologies, desire, discourse, climate, habitat and the physical entity of the plant itself. These elements circulated with the mango through botanic gardens all over the world and had a habit of remaining connected across borders even as they became localized. This

\footnotetext{
${ }^{8}$ Bruno Latour, "Circulating Reference: Sampling the Soil in the Amazon Forest," in Pandora's Hope: Essays on the Reality of Science Studies (Cambridge, MA: Harvard University Press, 1999).

${ }^{9}$ Ibid., p.29.
} 
meant that mangoes looked different and the same in each place that they appeared. While the regulated system of European science allowed for exchange across borders, transnational botanical science constantly translated mangoes along long chains of distance. This enabled the creation of colonial knowledge and colonial environments that had local consequences. Such consequences were rarely accounted for in the desires and directions of those who it was presumed had control of plant exchanges. Tracing the movements and translations of mangoes through the colonial botanic garden begins with their collection as a curiosity in colonial India by Europeans.

Botanical collectors played an important role in beginning the process of moving mangoes into colonial botanic gardens. Plant hunters were generally associated with places new to Europeans. Places like Australia were presented as a tabula rasa on which science could inscribe their discovery of the new world. The mango was an anomaly to this system. Rather than providing evidence of untamed, unknown places of the globe, this fruit grew in the horticultural sophistication of a non-European culture. Mangoes entered botanical records as a cultivated plant not as a wild one. The evidence of orchards of mango appeared in poem, narrative, statues, art and other texts in a 4,000 year span of Indian history. ${ }^{10}$ Although said to originate in the Himalaya region, mangoes were found across India and in the Malayan peninsula. Travelers in the late sixteenth century, Abul Fazl writing in the Ain-i-Akbari or Linschoten in Voyages to the East Indie, both detailed the locations of mangoes across the sub-continent. ${ }^{11}$ George Watt, writing in 1891, detailed the wide variety of uses for the mango. Both Hindu and Muslim physicians used parts of the mango in broths and dried form to relieve a variety of medical ailments. The flower, flesh, kernel, bark and leaves were all valued in India with wide ranging applications. Apart from its inclusion in cuisine, mango was also used as a gum arabic, a dye, tan and mordant in the leather trade, and as a part of Hindu ceremony. $^{12}$

\footnotetext{
${ }^{10}$ D McE Alexander, "The Mango in Australia," (Melbourne: Commonwealth Scientific and Industrial Research Organisation, Australia, 1986), Andre Kostermans and Jean-Marie Bompard, The Mangoes: Their Botany, Nomenclature, Horticulture and Utilisation (London: Academic Press, 1993), Lal Behari Singh, "History, Origin, Nomenclature, Distribution," in The Mango: Botany, Cultivation and Utilization (London: Leonard Hill Books Ltd, 1968), Washington Teasdale, "The Mango and Its Varieties," The Garden 3 (1873).

${ }^{11}$ Cited in George Watt, Dictionary of the Economic Products of India, vol. 5 (Calcutta: Department of Revenue and Agriculture, Government of India, 1891), p.147.

${ }^{12}$ Ibid., pp.146-57.
} 
The creation of a herbarium specimen altered these knowledges. Drying the leaf, branches, flowers and seeds of the mango allowed plant hunters to move plants out of their habitats in India. It was here that a transformation began, the plant was no longer Indian, or of Indian culture, but started to lose narratives of its original habitat and became a plant of imperial possibilities. Londa Schiebinger refers to this process as a narrative stripping, where the narratives of the colonized, give way to the science of the colonizer. ${ }^{13}$ This does not happen overnight. No historical time can be found to match this moment. Instead a seeping occurred; a process of disassembling and reassembling. What was certain was that this process began in the field as plants were pressed to remove moisture and then mounted the elements together on paper to form a herbarium specimen.

When seeds and fruit were too large or bulky, as they were with mature samples of mango, they were collected in bottles and suspended in alcohol. The botanist then added other information that was pertinent to the specimen. The places of collection, the date, the taxonomic classification were all provided in labels. ${ }^{14}$ The earliest specimen of mango held in the Royal Botanic Gardens, Sydney included its name, collection location, collection date and initials of the collector. The stated function of the herbarium sheet for the botanist was providing an 'unchanging record or evidence by means of which other plants, living or dead, may be compared and verified'. ${ }^{15}$ These sheets acted as reference points, in order that classification and systematics continued in an effort to complete a final mapping of plant location and type all over the world. In the process Indian knowledges partially disappeared.

The sheets had another function. They made plants travel as information. These sheets, pressed and ordered were neatly arranged and so enabled transportation of mangoes away from India. As information the herbarium sheet allowed botanists in Europe to process information about other parts of the globe. Herbarium specimens combined with other information that Carolus Linnaeus used to classify the plants in his Species

\footnotetext{
${ }^{13}$ Londa Schiebinger, Plants and Empire: Colonial Bioprospecting in the Atlantic World (Cambridge, Mass: Harvard University Press, 2004), p.87.

${ }^{14}$ L H Bailey, How Plants Got Their Names (New York: The Macmillan Company, 1933), pp.52-65.

${ }^{15}$ Ibid., p.46.
} 
Plantarum. ${ }^{16}$ At that time no live mango plants had been cultivated in Europe. Herbaria, both institutional and private, acted in the same manner as a library, providing the same type of reference point for the botanist. They became the footnotes to the global environment. The act of providing a systematic form of information on herbarium sheets meant that regardless of the place to which a sheet might travel, it could be read. The sparse additional information helped to minimize problems of translation.

The botanical illustration follows a similar pattern of representation as the herbarium specimen and provides another layer of information. Although an art form, botanical illustration has developed as an important layer in the science of botany. ${ }^{17}$ The illustration was a form of description of the plant. Like the herbarium specimen it also aimed at accurate representation of not only the form of the grown plant, but also the stages of a plants' development. The botanical illustration of the mango in Curtis's Botanical Magazine includes the leaf, the flower, the fruit, and the seed. ${ }^{18}$ While the herbarium specimen provides a dead and lifeless version of the plant, the illustration uses dimensional representation and especially as the technology improved, the use of colour. In this way it supplemented the herbarium specimen in providing another layer in the information of plants. Illustration was undertaken both as field work and as part of the laboratory work.

Although large volumes of living material collected in the field were transported around the globe, failure rates were very high. Collectors experimented with different mediums for transporting seeds including moss, soils and oakum. ${ }^{19}$ Moisture needed to be removed and insect infestation often spoiled successful transfer. Additionally many seeds did not survive the trips due to the varied rates of germinability; they simply did

\footnotetext{
${ }^{16}$ William Roscoe, "On Artificial and Natural Arrangements of Plants: And Particularly on the Systems of Linnaeus and Jussieu," Transactions of the Linnean Society of London 11 (1810), D. Onno Wijands and Johannes Heniger, "The Origins of Clifford's Herbarium," Botanical Journal of the Linnean Society 106, no. 2 (1991).

${ }^{17}$ Helen Hewson, Australia: 300 Years of Botanical Illustration (Collingwood: CSIRO Publishing, 1999), pp.3-14.

${ }^{18}$ William Jackson Hooker and John Smith, "Mangifera Indica Mango Tree," Curtis's Botanical Magazine LXXVI (1850): plate 4510.

${ }^{19}$ Joseph Banks, "Rules for Collecting and Preserving Specimens of Plants," in Papers of Sir Joseph Banks (Sydney: nd), Frederick V. Colville, "Directions for Collecting Specimens and Information Illustrating the Aboriginal Use of Plants," Bulletin of the United States National Museum, no. 39 (1895), Mr Lee, "Rules for Collecting and Preserving Seeds from Botany Bay," in Australian Joint Copying Project, Royal Botanic Gardens Kew, Correspondence (Sydney: nd).
} 
not live long enough to survive the distances traversed. Prior to 1838, living plants had a lower chance of survival on journeys across vast oceans. This accounts for the higher rate of transfer of dried material before this time. However, at that time the Wardian case, a travelling terrarium, specifically designed for plant transfer on shipping, improved the success rates. ${ }^{20}$ Mango plants travelled as both seed and seedling. The Royal Botanic Gardens, Kew received a shipment of mango seeds from Trinidad in 1821, where they had been grown as an imported plant. ${ }^{21}$ The mango exchanges to Kew did not always operate from a plants point of origin, here India, but from other places as well. Such a movement shows that the traffic of mangoes was not simply colony to centre, but that somewhere in the travels of the mango it had arrived in Trinidad. The importance of growing plants like the mango in botanic gardens in Trinidad, Kew and India was that it allowed for the representation of the plant to be supplemented by another form: a living one.

When seeds and living plants did survive journeys across the globe, they were planted into gardens, the most obvious of which were local botanic gardens. Acclimatisation societies, agricultural societies, nursery gardens and private estates all also participated in this movement of living material. The living collections of botanic gardens acted as another layer in the translation of plants from live object to a feature of science, in ways in which other types of gardens may not have partaken. They supplemented the herbarium specimen and the botanical illustration because these gardens were also repositories for these other types of information. Charles Moore, director of the Botanic Gardens, Sydney reported to the colonial government in 1849 on the commencement of work in the Lower Garden 'for the purpose of illustrating the natural orders included in the class "Monochlamydae"'.22 These orders were replicated in writing, representation and in the garden beds. Where the two dimensional representations collapsed time, the living specimen gave a tactile three dimensional sense to the plants and places of the globe and as such presented the mango in tune with the rhythms of local Australian

\footnotetext{
${ }^{20}$ Brockway, Science and Colonial Expansion: The Role of British Royal Botanic Gardens, pp.86-87, Calestous Juma, "Explorations in Historical Botany," in The Gene Hunters; Biotechnology and the Scramble for Suitable Seeds (London: Zed Books, 1989), pp.47-48, McCracken, Gardens of Empire: Botanical Institutions of the Victorian British Empire, pp.92-98.

${ }^{21}$ Lockhardt, "List of Imported Plants Numbered with Rhombood Pieces of Lead in the Following Size," in Royal Botanic Gardens Kew, Correspondence, Australian Joint Copying Project (Sydney: 1821), M 757 p.81.

${ }^{22}$ Charles Moore, "Report from the Director of Botanic Gardens, Sydney," (Sydney: New South Wales Votes and Proceedings, 1849), p.1.
} 
seasons. The mango, transported from its indigenous habitats in South East Asia and displaced through Kew, was re-presented and represented in Australia through this layered and multitextual process as both species from a local place and part of a larger global environment. In these locations the mango became "scienced", connected to the imperial power/knowledge nexus of botany. The mango was translated from an Indian plant, mobilised in a range of local matrixes and becomes Mangifera indica, Linn., an object read through this range of scientific representations.

Once the mango was established in this knowledge system, botanists could then read their location relationally, not as part of a natural ecosystem, but as part of an artificial grouping together with other plants. At the same time that mangoes became transnational botanic specimens they also became nationalized through declarations of indigeniety. The Flora was a special botanical resource that was related to concepts of territory. ${ }^{23}$ A Flora marks out or establishes the boundary first and then systematically classifies, identifies and notates all of the plant material that was contained in that territory. This was directly related to the boundaries that were forming through the process of colonisation and nationhood. Material was classified through the accumulated collection of botanical descriptions. The mango was presented in the Flora Indica by Joseph Dalton Hooker and Thomas Thomson; ${ }^{24}$ The Flora of British India by Joseph Dalton Hooker $^{25}$ and the Flora of the Malay Peninsula by Henry Ridley. ${ }^{26}$ Invariably, these Floras were undertaken in Europe using the types of information that had travelled from colonies and distant territories. A scientist such as Hooker, completing his Flora of British India did so at the Royal Botanic Gardens, Kew, thousands of miles away from the territories under scrutiny. This reinforces not only the importance of a transnational accessibility of information, but also the necessity of the layers of information to faithfully re-present species. Plants lost their material place in habitats and instead became part of transnational science. In the Royal Botanic Garden, Kew the mango did not remain as pure science. The accumulation of knowledge about

\footnotetext{
${ }^{23}$ A Flora relates to botany to territory and may be compared with a Florilegium which is a book of flowers.

${ }^{24}$ Joseph Dalton Hooker and Thomas Thomson, Flora Indica: Being a Systematic Account of the Plants of British India, Together with Observations on the Structures of Their Natural Orders and Genera (London: Pamplin, 1855).

${ }^{25}$ Joseph Dalton Hooker, The Flora of British India (London: Reeve \& Co, 1879).

${ }^{26}$ Henry N Ridley, The Flora of the Malay Peninsula (London: Reeve \& Co, 1922).
} 
mangoes stimulated further translation and movement. Floras mark one way in which this travelling information stimulated the development of other information: mangoes became commercial economic botany.

The mango became a potential crop of tropical agriculture. In order for this change to occur mangoes moved across the colonial botanic gardens. Not simply from India to Kew and then to Australia, but instead they criss-crossed the globe. Australian botanic gardens received mangoes from Trinidad, Pamplemousses, Calcutta and Java. One of the ways that acclimatization was transferred with the mangoes was through the compilation of catalogues of plants grown in a specific place. The earliest such list in the Sydney Botanic Gardens was compiled during Charles Fraser's superintendency in 1828. It was entitled 'List of esculent vegetables and pot herbs cultivated in the Sydney Botanic Gardens December 1827' ${ }^{27}$ However, other catalogues were also compiled during both Charles Moore's $1848-1896^{28}$ and Joseph Maiden's 1896-1924 ${ }^{29}$ directorships. These catalogues were used both locally as guides to the respective gardens and they also served the function of delimiting a living collection. It presented the contents of the place, replicating in part the role of the Flora by attaching plants to a particular territory. Australian botanists were already familiar with the territorial function of Floras. A catalogue draws this work to a local level, specific to local place.

In addition to this function, catalogues made mangoes part of a fluid system of transnational science. When a director in Australia received a catalogue of plants from botanic gardens in India, for example, this was a way of considering plants that may favourably grow here. Although a catalogue presented as a static document, within botanic gardens they were conduits of information about the viability of plants like mango. In the notice preceding the 1866 Catalogue of the Sydney Gardens it states as their purpose: 'to offer such information as is necessary to secure advantageous system of exchange with Botanists and Horticulturalists of other Countries, to whom both the

\footnotetext{
${ }^{27}$ Charles Fraser, "List of Esculent Vegetables and Pott Herbs Cultivated in the Botanic Gardens, Sydney," in Royal Botanic Gardens Sydney Special Collection Series B1 (Sydney: 1827).

${ }^{28}$ Charles Moore, "A Census of the Plants of New South Wales," in Royal Botanic Gardens Special Collection (Sydney: 1884).

${ }^{29}$ B Jones, "Plants in Botanic Gardens Sydney 1894-5," in Royal Botanic Gardens Sydney Library Manuscripts Collection (Sydney: 1894-5).
} 
possessions and wants of this Establishment will thus be made obviously apparent. ${ }^{30}$ In this way, the catalogue became a means of transferring information about the viability of growing particular plants within a comparative range of environmental conditions.

In 1884 Charles Moore created a census of the plants of New South Wales ${ }^{31}$ and had the list published into a small bound volume. His successor, Joseph Maiden reprinted this volume and sent it out to other institutions. How many he sent, or who he sent them to cannot be answered. However, six of these volumes survive in the Sydney Botanic Gardens collection to demonstrate how the botanists of Museo Nacional de Beunos Aries; Buitenzorg, Java; and University of California Berkeley, Calif, USA used these documents to compare to their own collections. The catalogues were marked to show which species were desired and then returned to Maiden. Maiden then used these documents to prepare shipments of plant material to these places. Information travelled backward and forward through these channels enabling mangoes and other plants to move from India to England to Sydney, and then on to South America, Indonesia and the USA. ${ }^{32}$

The collection of catalogues from other countries offered directors the opportunity to source desired plant material from places beyond the respective colonial, national and empire boundaries. ${ }^{33}$ In these ways the global environment was transferred from one place to the next. Two types of mango were listed as growing in the Sydney Botanic Gardens in 1866 and mangoes have been grown in the gardens ever since. As a seed or seedling was accepted from Calcutta, or Trinidad, or Kew and reared in Sydney, this demonstrates across boundaries the adaptability of the plant and demonstrated to other botanic gardens the possibility of growing mangoes, sustained by an information system specifically developed to support such exchange about economically viable plants.

\footnotetext{
${ }^{30}$ Government Botanic Gardens Sydney, "Catalogue of Plants in the Government Botanic Gardens Sydney, New South Wales," in Royal Botanic Gardens Sydney Special Collection (Sydney: 1866).

${ }^{31}$ Charles Moore, "A Census of the Plants of New South Wales," in Royal Botanic Gardens Special Collection (Sydney: 1884).

32 These 6 copies are shelved within the general library collection at the Royal Botanic Gardens Sydney Library.

${ }^{33}$ These exchanges are in no way limited to the British Empire but traveled readily across boundaries creating links between places like Sydney and those as far a field as Russia.
} 
In fact, the mango was not an easy live plant to move, neither the seed nor seedling stock travelled well, often dying in transit, reinforcing the importance of other ways of presenting the plant. Despite this difficulty, during the nineteenth century it did move: from Assam to Malaya by the British or by Indian colonial workers, or into Brazil by the Portuguese, to Jamaica, Mauritius and Haiti by the English and to Central Africa by earlier travellers of the Indian Ocean. ${ }^{34}$ Along with textual information, knowledge about propagation and cultivation of this very 'unstable' plant was also relocated out of India. The mango, if left to its own devices, goes wild, it transforms itself into the most amazing range of naturally evolved hybrids. Partly this was evidenced in the classification of more than 200 varieties in the most recent botanical work in 1993 by Andre Kostermans and Jean-Marie Bompard and the continuing quest for new native varieties. $^{35}$

In order to assure the quality of the fruit, technology of cultivation used by Indian gardeners and horticulturalists ${ }^{36}$ had to travel with the plant as it was relocated all over the globe. The most important feature of this technology was a specialised graft called inarching or approach graft which protects the quality of the fruit. These types of knowledges about cultivation, ostensibly passed on from one generation of gardeners to the next orally, were operating in European, colonial and indigenous cultures. When Britain originally attempted to move tea into the Himalayas in India the venture failed. It was only when Robert Fortune added both information and gardeners from China into Assam and Darjeeling that the plant was successfully relocated. ${ }^{37}$ The plant alone will not do, gardening knowledges also needed to move. As the mango moved, some technologies like the grafting process, moved with it but others such as its medicinal use remained as local knowledges in India.

\footnotetext{
${ }^{34}$ Lal Behari Singh, The Mango: Botany, Cultivation and Utilization (London: Leonard Hill Books Ltd, 1968), pp.1-10, 91-107.

${ }^{35}$ Kostermans and Bompard, The Mangoes: Their Botany, Nomenclature, Horticulture and Utilisation.

${ }^{36}$ Z, "The Mangoes and Its Varieties," The Garden, no. October 11 (1873): p.299.

${ }^{37}$ Calestous Juma, The Gene Hunters; Biotechnology and the Scramble for Suitable Seeds (London: Zed Books, 1989), p. 49.
} 
Horticulturalists Guy Adriance and Fred Brison state that this particular method of grafting was used in plants difficult to cultivate by other asexual cultivations. ${ }^{38}$ If seedling plants were used then variety occurs in the fruit, grafting eliminates the variability. The inarching or approach graft takes a seedling tree, grown to a rigorous stage and then the branch material of an established fruiting variety was grafted onto the root stock of the new plant. Instead of a new tree with a variable and inconsistent mango quality, the grafted variety replicates the parent tree with an assured fruit quality. If the cultivation of the mango as commercial economic botany was to be assured, it was as much by the movement of this specialised technique as it was by other methods. This demonstrates that although the written systems were privileged in transnational science, oral traditions were also important in information movement in horticultural work.

Particular climatic conditions needed to prevail for the mango to be successfully cultivated. Once knowledge of the plants' existence had moved, English gardeners were stimulated into providing artificial environments to allow for growth of tropicallyspecific plants. It was a desire for the fruit that Joseph Banks saw as a stimulus for the development of technologies that would allow its progress as commercially successful product within fifty years. He believed it would move from an unknown plant to a luxury item for the rich and eventually be commonly bought at marketplaces like Covent Garden. He states:

It does not require the gift of prophecy to foretell that before long the Aki and the Avocado Pear of the West Indies, the Flat Peach, the Mandarine Orange and the Litchi of China, the Mango, the Mangostan, and the Durion of the East Indies, and possibly other valuable fruits, will be frequent at the tables of opulent persons; and some of them perhaps in less than half a century, be offered for sale on every market day at Covent Garden. ${ }^{39}$ (Original emphasis)

Banks was confident that with the development of the hot houses or stove houses that changed the viability of the cultivating the fruit in the cold climates of Europe would eventually change the marketplace for all. Here we see the change for Banks of the mango from a plant of curiosity as it transferred into a scientific object and then into a

\footnotetext{
${ }^{38}$ Guy W Adriance and Fred R Brison, Propagation of Horticultural Plants (New York: McGraw Hill Book Company, 1939), p.199.

39 Joseph Banks, "On the Forcing-Houses of the Romans, with a List of Fruits Cultivated by Them, Now in Our Gardens," Transactions of the Horticultural Society 1 (1809): p.151.
} 
plant with the prospect of 'marketability' through the addition of the hot house technology.

Crucial to the development of such technologies was the exchange of information about them. From the more formal journals such as the Transactions of the Linnean Society to the popular magazines such as The Garden and The Gardener's Chronicle, information about experimentation with plant material, technical aspects such as grafting and the artificial environments were all reported and disseminated through networks that developed around botany. Helen Cohn argues that 'the increasing acceptance of periodicals as an effective and timely means of circulating scientific information' was enacted between botanic gardens all over the world during this period. ${ }^{40}$ Hot housing for the successful growth of mangoes was a good example of this type of exchange. Diagrams and dimensions of buildings, methods of heating, optimum temperatures were all variables reported by the gardening community which extended through botanic gardens and into settler communities. ${ }^{41}$ In this manner, information moved from the locality of the experimentation, usually a metropolitan centre, back to the point of origin of the plant itself, usually a colonial periphery or alternatively to other places with an interest in introducing exotic fruits for settlers like Australia. In addition, information travelled to places in which the conditions for growth of tropical fruit trees prevailed.

Beyond the technical and physical understandings of the plant, these journals also carried other provocative stories about food local to other global places. A plant such as the mango, which proved difficult to grow in Europe, also needed to carry stories about the desirability of the fruit. One account endeavours to delight 'the stranger at one time with its delicious flavour ${ }^{42}$ encouraging readers to seek out this fruit for its exotic taste. Similarly methods of how to eat and prepare fruits like the mango travelled in these magazines. Journals and magazines published in England but distributed through botanic gardens libraries throughout the world, were instrumental in detailing the qualities of the plants like the mango. Scientific information was supplemented with

\footnotetext{
${ }^{40}$ Helen M. Cohn, "Australian Plants, the Garden and Botany in the Nineteenth Century Periodical," Naturae, no. 5 (1995): p.4.

${ }^{41}$ Banks, "On the Forcing-Houses of the Romans, with a List of Fruits Cultivated by Them, Now in Our Gardens.", "House for Growing the Mango and Mangosteen," Journal of Horticulture and Cottage Gardener, no. December 5 (1865), "Tropical Fruit and Economic Trees," The Illustration Horticole 1 (1874).

42 "The Best Fruit Drier," The Garden 3, no. September 13 (1873).
} 
anecdotes and tales about the mango and as this knowledge grew, settlement stimulated experimentation with the fruit as a crop plant. Tropical colonies offered an alternate scenario in the supply of mangoes to the market.

James Carne Bidwell planted and tended a garden at Tinana near Maryborough in Queensland whilst acting as a Land Commissioner for the Wide Bay district in the late 1840s. Bidwell was an avid gardener; he keenly worked on breeding and acclimatising interesting plants in this remote place. ${ }^{43}$ His spent his life working as a botanical collector, gardener for the Macarthur family at Camden, employee at Kew and finally and briefly a director of the botanic gardens, Sydney. This placed him in a position of great knowledge both about Australia and transnational botany. ${ }^{44} \mathrm{He}$ was connected to the network of transnational science largely through his avid letter writing maintaining frequent correspondence with William Hooker at Kew as well as other notable nineteenth century Europeans gardeners and botanists. He understood that this connection, through correspondence, placed him in a relationship with the movements and mobility of plants, plant material and plant information. At this juncture in the movement of the mango in Australia they became a settler experiment.

Correspondence between such people was a lively part of exchange about plants like the mango. In this way information about acclimatisation, exchange, climate, soils, technologies, horticultural practice, usefulness and ornamental features supplemented the reductive representations of science. Bidwell used his familiarity with transnational science to request 'a case of mangoes' from the Calcutta Gardens through correspondence with Hooker at Kew in $1849 .{ }^{45}$ Bidwell was able to start a garden of tropical fruits that he hoped would eventually supply stock to 'all the tropical lands of Australia'. ${ }^{46}$ Exposure to the ideas and exchanges of mangoes which occurred across these places fuelled Bidwell's optimism. He had the ability to combine that knowledge of local environmental conditions to trial the mango as a 'new' tropical fruit crop. He sought to enact changes that resulted in a different way of understanding this local

\footnotetext{
${ }^{43}$ Colin Mills, "The Case of the Missing Notebook," Australian Garden History 18, no. 1 (2006).

${ }^{44}$ Thom Blake, "'This Noble Tree': J.C. Bidwell and the Naming of the Bunya Pine," Queensland Review 9, no. 2 (2002): pp.39-42.

${ }^{45}$ J C Bidwell, "Letter to William Hooker," in Australian Joint Copying Project, Royal Botanic Gardens, Kew (Sydney: 1849).

${ }^{46}$ Bidwell, "Letter to William Hooker."
} 
place. He understood the mango as Indian, as commercial economic botany, as a desired food, as a symbol of settlement hope and he understood this through its place in transnational science. Unfortunately, Bidwill's dream died with him in 1853. The catalogue of plants of his garden undertaken upon Bidwell's death was a testament to his hopes and dreams. It showed a listing for Mangifera indica as well as other tropical fruits. ${ }^{47}$ Maryborough never became a centre for tropical fruit growth during this period; but others in Queensland also carried this dream.

Walter Hill, the director of the Brisbane Botanic Gardens, like Bidwell, saw the plant for its potential in relation to the development of agriculture along the seaboard of the colony of Queensland in the nineteenth century. During the 1870s and 1880s ten smaller botanic gardens were established along the Queensland coast and were all initially stocked with tropical fruit trees including the mango. ${ }^{48}$ Each site represented a potential economic beginning for a local fruit industry. Mangoes were trialed in all of these places to demonstrate to local communities the possibilities of adapting this fruit to a particular climate and an emerging settler economy. Agriculture, however, during this phase of Queensland's development focused on sugar, for which there was a robust international and domestic market. Mangoes, trickier to grow, harvest, and store for distant markets were spurned by local farmers. These mangoes became an experiment that failed. They did go on to become a feature of the Queensland fruit industry, but as CSIRO scientist D. Alexander shows the industry was not properly established until well into the twentieth century. ${ }^{49}$

Instead of becoming commercially successful plants they became imbedded in the domestic - but informal - economy of Queensland backyards. ${ }^{50}$ So, like the mango that lost its local knowledge in the movement between India and Kew, the mango here changed from a plant with the potential for commercial economic botany to become

\footnotetext{
${ }^{47}$ Charles Moore, "Catalogue of Plants at Tinana," in Private collection held by Maryborough City Council (Maryborough: 1854).

${ }^{48}$ Jodi Frawley, "The Queensland Botanic Gardens Context Study," (Brisbane: Environmental Protection Agency, 1999).

${ }^{49}$ D McE Alexander, "The Mango in Australia," (Melbourne: Commonwealth Scientific and Industrial Research Organisation, Australia, 1986).

${ }^{50}$ Andrea Gaynor, Harvest of the Suburbs: An Environmental History of Growing Food in Australian Cities (Crawley, W. A.: University of Western Australia Press, 2006).
} 
something quite different. The articulation as commercial economic botany did not hold. As D. Buchanan of Mackay noted in The Gardeners' Chronicle

the fruit here is of no value, except for family consumption, and what are eaten by cows, as there is no market for them. Boys and girls come out of town and carry away loads of them but no one thinks of buying them. ${ }^{51}$

Instead mango trees thrived in the backyards of Queensland homes. They provided a bountiful supply of fruit for the family in the suburbs. Such was the volume of fruit that preservation in the form of stewing, chutney making, and bottling were all undertaken within this local understanding of the plant. The climate, geography and palatability of the plant posed no problem within the settler communities in Queensland.

One of the elements that was lost in this transit was the need to provide an inarching graft that had travelled from the Indian orchards to the Australian botanic gardens. Instead the plants that cropped up in backyards were self seeded and thus had variable fruit quality. As Washington Teasdale argued:

The cultivated Mango is unique and exceptional as a real dessert fruit, with a luscious flavour, unlike any other, and not to be described. In the wild Mango the stringy fibres usurp most of the pericarp, tainting it with resin. ${ }^{52}$

Fruit bearing maturity took up to five years for mangoes. It was only at this time that settlers discovered whether their tree had produced the sweet succulent exotic taste of the tropics, or the bitter turpentine flavour that saw mangoes turned over to the local birds, possums and cattle. Without the surety of horticultural practice, flavour was a hit and miss affair. Given the volume of mangoes produced from each tree, this mattered little in the backyard consumption of the fruit, with sweet mangoes shared amongst neighbours and friends.

Objects that traveled through the transnational systems of science had the capacity to both lose important narratives from their places of origin and gather new meanings and associations in a new place. The narrative stripping, that Schiebinger argued for, was

\footnotetext{
${ }^{51}$ D Buchanan, "Queensland - Mango Culture," The Gardener's Chronicle, no. December 20 (1902): p.462.

${ }^{52}$ Washington Teasdale, “The Mango and its Varieties,” The Garden, October 11 (1873): p.298.
} 
always accompanied by a process of re-clothing; of re-emergence rather than disappearance. Despite the loss of some narratives in the process of travel, such as the medicinal use of mango and mango products in India, mangoes developed into new environments in Queensland. Opportunity was provided through the fortuitous availability of plants that initially passed through botanic gardens, and the hands of renowned botanists of settler Australia. This was a simultaneous shifting in the value attributed by different sectors of the community - as the scientific support for agricultural development through fruit cropping diminished, home grown mangoes emerged.

It is hard to find such a link in the previous histories of botanic gardens. In the terms of 'improvement' or 'colonial expansion' or 'green imperialism' botanic gardens surely failed to deliver on their promise of successful transplantation of the mango for the commercial betterment of the colony of Queensland. It was not that the object changed, but the enabling local environment surrounding it had changed. Botanic gardens and transnational science all played a role in the eventual location of mangoes in tropical backyards but that was never an intention of these large-scale systems of science. The grand narrative of colonial science, as such, fails as an explanation and instead must be replaced with a focus on the local consequences of the movement of mangoes. Botanic gardens were transit places that stimulated environmental change in unexpected and unplanned ways through the movement of mangoes and a myriad of other plants. The landscape of meaning was multiplied in this process and mangoes were found in a series of places and times.

While various locations can be discerned for the mango none were discreet, each one was bound up with the next. India was found in the translation of the plant into a specimen of transnational science. Nineteenth century Australian botanic gardens moved mangoes through their ability to access plants, plant material and plant information in a fluid and non-specific way. Kew was implicated in the shift from a colonial laboratory to a way of thinking about the plant as an experimental commercial crop in Queensland. Botanic gardens in Sydney, Calcutta, Trinidad and Brisbane were all places for mangoes to live and places for transiting mangoes. Even as a backyard fruit, the most local of the articulations, the mango carries with it traces of belonging to other parts of the world. What does it mean that chutney making, an Indian method of 
food preservation, was also favoured in Queensland? In this way, plants like the mango became global artefacts, both as information and as live plants, as a cultural product which made its way to the table in places all over the world.

\section{Bibliography}

Adriance, Guy W, and Fred R Brison. (1939) Propagation of Horticultural Plants. New York: McGraw Hill Book Company.

Alexander, D McE. (1986) "The Mango in Australia." Melbourne: Commonwealth Scientific and Industrial Research Organisation, Australia.

Bailey, L H. (1933) How Plants Got Their Names. New York: The Macmillan Company.

Banks, Joseph. (1809) "On the Forcing-Houses of the Romans, with a List of Fruits Cultivated by Them, Now in Our Gardens." Transactions of the Horticultural Society 1: 147-56.

_ (nd) "Rules for Collecting and Preserving Specimens of Plants." In Papers of Sir Joseph Banks. Sydney.

_ (1873) "The Best Fruit Drier." The Garden 3, no. September 13: 219.

Bidwell, J C. (1849) "Letter to William Hooker." In Australian Joint Copying Project, Royal Botanic Gardens, Kew. Sydney,.

Blake, Thom. (2002) "'This Noble Tree': J.C. Bidwell and the Naming of the Bunya Pine." Queensland Review 9, no. 2: 39-46.

Brockway, Lucile. (1979) Science and Colonial Expansion: The Role of British Royal Botanic Gardens. New York: Academic Press.

Buchanan, D. (1902) "Queensland - Mango Culture." The Gardener's Chronicle, no. December 20: 462.

Cohn, Helen M. (1995) "Australian Plants, the Garden and Botany in the Nineteenth Century Periodical." Naturae, no. 5: 1-24.

Colville, Frederick V. (1895) "Directions for Collecting Specimens and Information Illustrating the Aboriginal Use of Plants." Bulletin of the United States National Museum, no. 39: 3-8.

Desmond, Ray. (1998) Kew: The History of the Royal Botanic Gardens. London: Harvill in association with the Royal Botanic Gardens Kew.

Drayton, Richard. (2003) Nature's Government: Science, Imperial Britain and the 'Improvement' of the World. New Haven: Yale University Press. 
Fraser, Charles. (1827)."List of Esculent Vegetables and Pott Herbs Cultivated in the Botanic Gardens, Sydney." In Royal Botanic Gardens Sydney Special Collection Series B1. Sydney.

Frawley, Jodi. (1999) "The Queensland Botanic Gardens Context Study." Brisbane: Queensland Environmental Protection Agency.

Gaynor, Andrea. (2006) Harvest of the Suburbs: An Environmental History of Growing Food in Australian Cities. Crawley, W. A.: University of Western Australia Press.

Government Botanic Gardens Sydney. (1866) "Catalogue of Plants in the Government Botanic Gardens Sydney, New South Wales." In Royal Botanic Gardens Sydney Special Collection. Sydney.

Grove, Richard. (1995) Green Imperialism : Colonial Expansion, Tropical Island Edens, and the Origins of Environmentalism, 1600 -1860, Studies in Environment and History. Cambridge ; New York: Cambridge University Press.

Hewson, Helen. (1999) Australia: 300 Years of Botanical Illustration. Collingwood: CSIRO Publishing.

Hooker, Joseph Dalton. (1879) The Flora of British India. London: Reeve \& Co.

Hooker, Joseph Dalton, and Thomas Thomson. (1855) Flora Indica: Being a Systematic Account of the Plants of British India, Together with Observations on the Structures of Their Natural Orders and Genera. London: Pamplin.

Hooker, William Jackson, and John Smith. (1850) "Mangifera Indica Mango Tree." Curtis's Botanical Magazine LXXVI: pl. 4510.

"House for Growing the Mango and Mangosteen." (1865) Journal of Horticulture and Cottage Gardener, no. December 5: 464.

Jones, B. (1894-5) "Plants in Botanic Gardens Sydney 1894-5." In Royal Botanic Gardens Sydney Library Manuscripts Collection. Sydney.

Juma, Calestous. (1989) "Explorations in Historical Botany." In The Gene Hunters; Biotechnology and the Scramble for Suitable Seeds, 37-65. London: Zed Books.

(1989) The Gene Hunters; Biotechnology and the Scramble for Suitable Seeds. London: Zed Books.

Kostermans, Andre, and Jean-Marie Bompard. (1993) The Mangoes: Their Botany, Nomenclature, Horticulture and Utilisation. London: Academic Press.

Latour, Bruno. (1999) "Circulating Reference: Sampling the Soil in the Amazon Forest." In Pandora's Hope: Essays on the Reality of Science Studies, 24-79. Cambridge, MA: Harvard University Press.

Lee, Mr. (nd) "Rules for Collecting and Preserving Seeds from Botany Bay." In Australian Joint Copying Project, Royal Botanic Gardens Kew, Correspondence, 118-19. Sydney. 
Lockhardt. (1821) "List of Imported Plants Numbered with Rhombood Pieces of Lead in the Following Size." In Royal Botanic Gardens Kew, Correspondence, Australian Joint Copying Project, 781. Sydney,.

MacLeod, Roy. (1982) "On Visiting the 'Moving Metropolis': Reflections on the Architecture of Imperial Science." Historical Records of Australian Science 5, no. 3: 1-16.

McCracken, Donal. (1997) Gardens of Empire: Botanical Institutions of the Victorian British Empire. London: Leicester University Press,.

Mills, Colin. (2006) "The Case of the Missing Notebook." Australian Garden History 18, no. 1: 4-7.

Moore, Charles. (1884) "A Census of the Plants of New South Wales." In Royal Botanic Gardens Special Collection. Sydney.

(1849) "Report from the Director of Botanic Gardens, Sydney." Sydney: New South Wales Votes and Proceedings.

Ridley, Henry N. (1922) The Flora of the Malay Peninsula. London: Reeve \& Co.

Roscoe, William. (1810) "On Artificial and Natural Arrangements of Plants: And Particularly on the Systems of Linnaeus and Jussieu." Transactions of the Linnean Society of London 11: 50-78.

Schiebinger, Londa. (2004) Plants and Empire: Colonial Bioprospecting in the Atlantic World. Cambridge, Mass: Harvard University Press,.

Singh, Lal Behari. (1968) The Mango: Botany, Cultivation and Utilization. London: Leonard Hill Books Ltd,.

Teasdale, Washington. (1873) "The Mango and Its Varieties." The Garden 3: 298-99. (1874) "Tropical Fruit and Economic Trees." The Illustration Horticole 1: 3031.

Watt, George. (1891) Dictionary of the Economic Products of India. Vol. 5. Calcutta: Department of Revenue and Agriculture, Government of India,.

Wijands, D. Onno, and Johannes Heniger. (1991) "The Origins of Clifford's Herbarium." Botanical Journal of the Linnean Society 106, no. 2: 129-46.

Z. (1873) "The Mangoes and Its Varieties." The Garden, no. October 11: 299. 